\title{
Mutational screening of the Wilms's tumour gene, WT1, in males with genital abnormalities
}

Paul A Clarkson, Helen R Davies, Denise M Williams, Rakesh Chaudhary, Ieuan A Hughes, Mark N Patterson

\begin{abstract}
Several lines of evidence suggest that the Wilms's tumour susceptibility gene, WT1, has an important role in genital as well as kidney development. WT1 is expressed in developing kidney and genital tissues. Furthermore, mutations in WT1 have been detected in patients with the Denys-Drash syndrome (DDS), which is characterised by nephropathy, genital abnormalities, and Wilms's tumour. It is possible that WT1 mutations may cause genital abnormalities in the absence of kidney dysfunction. We tested this hypothesis by screening the WT1 gene for mutation in $1246, X Y$ patients with various forms of genital abnormality. Using single strand conformation polymorphism (SSCP) we did not detect any WT1 mutations in these patients. However, in addition to the 12 patients, three DDS patients were also analysed using SSCP, and in all three cases heterozygous WT1 mutations were found which would be predicted to disrupt the DNA binding activity of WT1 protein. These results support the notion that DDS results from a dominant WT1 mutation. However, WT1 mutations are unlikely to be a common cause of male genital abnormalities when these are not associated with kidney abnormalities. ( $\mathcal{F}$ Med Genet 1993;30:767-72)
\end{abstract}

Abnormalities of the genital system resulting in an intersex phenotype are known to arise through a number of genetic mechanisms. When the affected subject has a normal male karyotype $(46, \mathrm{XY})$ the condition is described as male pseudohermaphroditism. Clinical malformations include micropenis (or clitoromegaly), cryptorchidism (undescended testes), and hypospadias (a misplaced urethral opening). Such phenotypes can arise from androgen biosynthetic defects, for example, $17 \beta$ hydroxysteroid dehydrogenase and $5 \alpha$-reductase deficiency. Alternatively, there may be a defect in the response to hormonal signals, as is seen in the androgen insensitivity syndrome, caused by mutations in the androgen receptor gene. ${ }^{2}$ In many cases neither hormonal synthesis nor the response appears defective, suggesting that a mutation in a gene which functions in another aspect of genital development may be the cause of the phenotype.

A recent addition to the genes currently known to be involved in genital development is WT1, which was originally isolated as a candidate for the Wilms's tumour predisposition gene on chromosome 11 band p13. ${ }^{34}$ Wilms's tumour is a childhood malignancy of the kidney, and in several tumours intragenic mutations of the WT1 gene have been found, thus confirming that WT1 is one of the genes involved in the development of Wilms's tumour. $^{5-7}$ The WT1 gene comprises 10 exons which encode a protein with amino acid sequence motifs characteristic of a transcription factor. $^{34}$ The four $3^{\prime}$ exons each encode zinc finger structures involved in DNA binding, and the WT1 protein has been shown to bind specifically to the DNA sequence recognised by the early growth response gene, EGR $1 .^{8}$ Furthermore, in transient transfection assays WT1 functions as a transcriptional repressor of genes containing the EGR1 target sequence. ${ }^{9}$ A subset of Wilms's tumours is therefore thought to arise from loss of function of WT1, leading to the deregulated expression of growth promoting genes and the uncontrolled growth of embryonic kidney cells.

The evidence that implicates WT1 in genital as well as kidney development comes from expression studies of WT1 and from genetic data. ${ }^{10} \mathrm{WT} 1$ is expressed in fetal kidney, genital ridge, and fetal gonad. ${ }^{112}$ The precise cell specific pattern of expression has led to the suggestion that WT1 is involved in mesenchymal-epithelial transitions in embryonic kidney and genital structures. ${ }^{11}$ More recently, WT1 mutations have been identified in subjects with Denys-Drash syndrome (DDS). ${ }^{13-16}$ This rare condition is characterised by a specific nephropathy, often accompanied by gonadal/genital abnormalities or Wilms's tumour or both. ${ }^{17}$ The syndrome affects both males and females. The genital phenotype is very variable but most often presents as male pseudohermaphroditism, with micropenis, cryptorchidism, or perineal hypospadias. True hermaphroditism has also been reported in DDS. ${ }^{18}$ In almost all cases studied, DDS subjects carry a heterozygous mutation in WT1 which is predicted to affect the ability of the WT1 protein to bind DNA. Constitutional mutations in WT1 were also reported in two subjects with Wilms's tumour, hypospadias, and cryptorchidism, but without nephropathy. ${ }^{19}$ These observations suggest that the genital abnormality in the WAGR syndrome (Wilms's tumour, aniridia, genitourinary abnormalities, mental retardation), which is associated with constitutional deletion of $11 \mathrm{p} 13$ is caused by deletion of the WT1 gene itself. Constitutional WT1 mutations therefore appear to act as dominant mutations and are associated with nephropathy or Wilms's tumour or both, in the presence or absence of genital abnormalities. 
The purpose of this study was to determine whether WT1 mutations cause genital abnormalities in the absence of nephropathy or Wilms's tumour. As part of a previous study, the androgen receptor gene was screened for mutation in a group of $46, \mathrm{XY}$ patients with various genital abnormalities compatible with a diagnosis of androgen insensitivity syndrome. ${ }^{20}$ In the majority of patients with phenotypes such as cryptorchidism, micropenis, and hypospadias, mutations in the androgen receptor gene were not found. It is therefore possible that other genetic defects account for the phenotypes in these patients. Given the association between WT1 mutations and the genital abnormalities in DDS, we screened WT1 for mutation in a cohort of $46, \mathrm{XY}$ patients with various genital abnormalities, but without any kidney dysfunction.

\section{Patients}

PATIENTS WITH GENITAL ABNORMALITIES

The phenotypes of the patients studied are summarised in table 1. Each had a normal 46,XY karyotype. All non-DDS patients were also analysed for androgen binding activity, and qualitatively normal binding was seen. Two patients (P1 and P4) had low levels of binding, but since this phenomenon has been observed in Denys-Drash syndrome, these patients were included. ${ }^{21}$ The androgen receptor gene had also been screened for mutation by PCR-SSCP in some of the patients, and in each case no evidence for mutation was found. The majority of the patients presented with severe undervirilisation (either predominantly male with perineal hypospadias, cryptorchidism, and micropenis, or predominantly female with clitoromegaly). The majority of patients also had apparently normal testes by histology or the hCG stimulation test which provides a measure of the ability of the testes to synthesise androgen in response to gonadotrophin. ${ }^{22}$ We also included one patient with true hermaphroditism (F14). This patient also presented with other congenital abnormalities, which included liver and CNS defects, and died shortly after birth.
DENYS-DRASH SYNDROME PATIENTS

Three DDS patients were included in this analysis, since mutations in WT1 were expected. Subject S12 was born with perineal hypospadias and cryptorchidism, suggestive of an undervirilised male. The karyotype was $46, X Y$ and ultrasound showed normal male internal genital anatomy and no Müllerian structures. There was a normal response to a three day hCG stimulation test. The initial diagnosis in this patient was partial androgen insensitivity syndrome (PAIS). At 9 months of age, however, S12 presented with Wilms's tumour and diffuse mesangial sclerosis, typical of DDS. This patient was investigated in an independent study. ${ }^{23}$ Patient R6 (also 46,XY) was born with the appearance of virilised female external genitalia (clitoromegaly, incomplete fusion of the labia, and rugose labioscrotal folds). Gonadal histology showed normal infantile testes, and there was a normal testosterone response to hCG. Pelvic ultrasound showed no Müllerian structures and a diagnosis of PAIS was again made. At 5 months of age she presented in established renal failure. A renal biopsy showed diffuse mesangial sclerosis, and a diagnosis of DDS was made. While awaiting renal transplantation, she developed peritonitis and overwhelming sepsis as a complication of her dialysis and died at $6 \frac{1}{2}$ months of age. Patient CAM114 $(46, \mathrm{XY})$ was born with normal external female genitalia and presented at 6 months of age with nephrotic syndrome. Histological examination of a renal biopsy showed diffuse mesangial sclerosis and a diagnosis of DDS was made. ${ }^{24}$ CAM114 was found at laparotomy to have internal female genital structures. This patient was also investigated in an independent study (corresponding to patient LB). ${ }^{15}$

\section{Materials and methods}

ANDROGEN BINDING ASSAY

Fibroblast cell lines were established for all patients from genital skin biopsies, obtained at surgery, as previously described.$^{20}$ Genital skin fibroblasts were assayed for androgen binding activity using a whole cell binding assay. ${ }^{25}$ The

Table 1 Summary of patient phenotypes.

\begin{tabular}{|c|c|c|c|c|}
\hline Patient code & Genital phenotype & Gonadal histology & $\begin{array}{l}\text { hCG } \\
\text { stimulation test }\end{array}$ & $\begin{array}{l}\text { AR gene } \\
\text { screened }\end{array}$ \\
\hline $\begin{array}{l}\text { Male pseudohermaphrodites } \\
\text { P1 } \\
\text { P4 } \\
\text { Y7 } \\
\text { C7 } \\
\text { H16 } \\
\text { H6 } \\
\text { F12 } \\
\text { X14 } \\
\text { G14 } \\
\text { A15 } \\
\text { H8 }\end{array}$ & $\begin{array}{l}\text { Male with micropenis, bifid scrotum, hypospadias } \\
\text { Female with clitoromegaly } \\
\text { Female with clitoromegaly } \\
\text { Male with micropenis, cryptorchidism, perineal hypospadias } \\
\text { Male with perineal hypospadias } \\
\text { Female with clitoromegaly } \\
\text { Male with perineal hypospadias, bifid scrotum } \\
\text { Male with micropenis, cryptorchidism, perineal hypospadias } \\
\text { Male with micropenis, bifid scrotum, perineal hypospadias } \\
\text { Female with clitoromegaly } \\
\text { Female with clitoromegaly }\end{array}$ & $\begin{array}{l}\text { Not done } \\
\text { Testes } \\
\text { Immature testes } \\
\text { Dysplastic testes } \\
\text { Not done } \\
\text { Not done } \\
\text { Not done } \\
\text { Not done } \\
\text { Testes } \\
\text { Testes } \\
\text { Testes }\end{array}$ & $\begin{array}{l}\text { Not done } \\
\text { Not done } \\
\text { Normal response } \\
\text { Normal response } \\
\text { Normal response } \\
\text { No response } \\
\text { Not done } \\
\text { Normal response } \\
\text { Normal response } \\
\text { Normal response } \\
\text { Normal response }\end{array}$ & $\begin{array}{l}\text { Yes } \\
\text { Yes } \\
\text { Yes } \\
\text { Yes } \\
\text { Yes } \\
\text { No } \\
\text { Yes } \\
\text { Yes } \\
\text { No } \\
\text { Yes } \\
\text { No }\end{array}$ \\
\hline $\begin{array}{l}\text { True hermaphrodite } \\
\text { F14 }\end{array}$ & Female with clitoromegaly & One testis, one ovary & Not done & No \\
\hline $\begin{array}{l}\text { DDS patients } \\
\text { S12 } \\
\text { R7 } \\
\text { CAM114 }\end{array}$ & $\begin{array}{l}\text { Male with cryptorchidism, perineal hypospadias } \\
\text { Female with clitoromegaly, labial fusion } \\
\text { Normal female external genitalia }\end{array}$ & $\begin{array}{l}\text { Not done } \\
\text { Testes } \\
\text { Not done }\end{array}$ & $\begin{array}{l}\text { Normal response } \\
\text { Normal response } \\
\text { Not done }\end{array}$ & $\begin{array}{l}\text { No } \\
\text { No } \\
\text { No }\end{array}$ \\
\hline
\end{tabular}

All patients have a normal male $46, \mathrm{XY}$ karyotype and, with the exception of the DDS patients who were not assayed, have normal androgen binding activity. 
radioactive ligand was ${ }^{3} \mathrm{H}$-dihydrotestosterone, and the method has been described in detail previously. ${ }^{20}$

\section{PREPARATION OF NUCLEIC ACIDS}

DNA was prepared either from fibroblast cell lines or from whole blood using standard methodology. Aliquots of genomic DNA were diluted to a concentration of $100 \mathrm{ng} / \mu \mathrm{l}$ for PCR. RNA was prepared from fibroblasts by the method of Chomczynski and Sacchi. ${ }^{26}$

PCR-SSCP ANALYSIS OF THE WTI GENE

The WT1 gene was screened for mutation by examining each exon amplified from genomic DNA by the polymerase chain reaction (PCR) for single strand conformation polymorphism (SSCP). ${ }^{2728}$ Intronic oligonucleotide primers were designed flanking each exon based on the published DNA sequence. ${ }^{2930}$ The sequences of the oligonucleotides are given in table 2 . The PCR fragments were all less than $300 \mathrm{bp}$. Exon 1 was analysed in two overlapping fragments because of its large size relative to other exons. Each PCR reaction contained $100 \mathrm{ng}$ genomic DNA, 4 pmol of the relevant oligonucleotide pair, 0.2 units $T a q$ polymerase (CamBio), $1 \mu 1$ Parr Excellence buffer (CamBio), $200 \mu \mathrm{mol} / \mathrm{l}$ deoxyribonucleotides, and $2 \mu \mathrm{Ci} \quad \alpha^{32} \mathrm{P}$ labelled deoxyadenosine triphosphate (dATP). The only exception to this was exon 1 . The 1S2/1A2 fragment of exon 1 was amplified using a buffer containing $10 \mathrm{mmol} / \mathrm{l}$ Tris (pH 8.8), $50 \mathrm{mmol} / 1 \mathrm{KCl}, \quad 1 \mathrm{mmol} / \mathrm{l}$ $\mathrm{MgCl}_{2}, 0.001 \%$ gelatin, $0.5 \%$ Tween $20,0.1 \%$ Triton X-100. The first part of exon 1 could not be reproducibly amplified, presumably owing to the high GC content of this region, and it was therefore not possible to analyse this region for mutation. After a three minute denaturation at $95^{\circ} \mathrm{C}, \mathrm{PCR}$ was carried out for thirty cycles as follows: $95^{\circ} \mathrm{C}$ denaturation for 30 seconds, annealing for one minute (temperatures given in table 2 ), extension at $72^{\circ} \mathrm{C}$ for one minute. This was followed by a final extension at $72^{\circ} \mathrm{C}$ for five minutes. Samples were analysed for mutation by SSCP analysis as described previously. ${ }^{20}$ Electrophoresis was carried out using a $20 \times 40 \mathrm{~cm}, 6 \%$ polyacrylamide gel, run at $25 \mathrm{~W}$, and incorporating fan cooling. Every sample was analysed using two sets of electrophoresis conditions: one gel was run at $4^{\circ} \mathrm{C}$ and the other was run at room temperature using a gel containing $10 \%$ glycerol.

\section{DNA SEQUENCING}

Variant fragments detected on SSCP gels were amplified for direct sequencing using the conditions described above, but excluding the radioactive dATP, scaled up to a total volume of $50 \mu \mathrm{l}$. The fragments were purified from low melting point agarose gels using the Magic PCR Preps ${ }^{\mathrm{TM}}$ system (Promega), and then sequenced directly using a cycle sequencing kit (Promega).

REVERSE TRANSCRIPTION-PCR (RT-PCR) ANALYSIS OF WT1 TRANSCRIPT

Patient F14 was found to carry a heterozygous WT1 mutation in intron 8 (see Results). The WT1 transcript was therefore analysed for a splicing abnormality at the exon 8 /intron 8 boundary in sample F14 by RT-PCR. A single PCR reaction did not produce a visible band on an agarose gel, and therefore two PCR reactions were carried out using nested oligonucleotide primers. Total RNA $(2 \mu \mathrm{g})$ prepared from genital skin fibroblasts was reverse transcribed $\left(42^{\circ} \mathrm{C}\right.$ for one hour) in a $20 \mu \mathrm{l}$ reaction which also included 10 units AMVRT (HT Biotechnology Ltd), $1 \mathrm{mmol} / \mathrm{l}$ dNTPs, $10 \mathrm{pmol}$ antisense primer, and reaction buffer $(50 \mathrm{mmol} / 1$ Tris $\mathrm{pH} 8.3,50 \mathrm{mmol} / 1$ $\mathrm{KCl}, 1 \mathrm{mmol} / 1 \mathrm{DTT}, 1 \mathrm{mmol} / 1 \mathrm{EDTA})$. The sequence of the antisense primer used for RT was TACCTGTATGAGTCCTGGTGTGG from exon 9. A $1 \mu$ l portion of the $\mathrm{RT}$ reaction was amplified by PCR $(10 \mu$ l reaction) using this primer and a sense primer from exon 7 whose sequence was TTGTACGGTCGGCATCTGAGACC. Subsequently, $2 \mu \mathrm{l}$ of this reaction was amplified using two internal primers: CTTCATGTGTGCTTACCCAGGCTGC from exon 7, and GTGGTCGGACCGGGAGAACTTTCG from exon 9. The PCRs were carried out as described above using an annealing temperature of $60^{\circ} \mathrm{C}$, and an extension time of three minutes. The products $(5 \mu \mathrm{l})$ of the RT-PCR were analysed by agarose gel electrophoresis.

\section{Results}

IDENTIFICATION OF PUTATIVE WT1 MUTATIONS BY PCR-SSCP

Each of the exons of the WT1 gene was analysed in turn on SSCP gels using two sets of conditions as described in the Methods. Evidence of a sequence variant is indicated by an aberrant banding pattern on the gel. Such variation was observed for all three DDS

Table 2 Oligonucleotide primers used for PCR amplification of the WT1 gene.

\begin{tabular}{|c|c|c|c|c|c|c|}
\hline Exon & $\begin{array}{l}\text { Sense } \\
\text { oligo }\end{array}$ & Sequence & $\begin{array}{l}\text { Antisense } \\
\text { oligo }\end{array}$ & Sequence & $\begin{array}{l}\text { Fragment } \\
\text { size (bp) }\end{array}$ & $\begin{array}{l}\text { Temp } \\
\left({ }^{\circ} \mathrm{C}\right)\end{array}$ \\
\hline $\begin{array}{r}1 \\
1 \\
2 \\
3 \\
4 \\
5 \\
6 \\
7 \\
8 \\
9 \\
10\end{array}$ & $\begin{array}{l}1 S 1 \\
1 S 2 \\
2 S \\
3 S \\
4 S \\
5 S \\
6 S \\
7 S \\
8 S \\
9 S \\
10 S\end{array}$ & $\begin{array}{l}\text { TCTGAGCCTCAGCAAATGGGCTCC } \\
\text { CATCAAACAGGAGCCGAGCTGG } \\
\text { CCGCTGACACTGTGCTTCTCTCC } \\
\text { GGCAGCACTCGCTCAGCTGTCTTCG } \\
\text { AACTCCATTGCTTTTGAAGAAACAG } \\
\text { GGCTTGCAGATCCATGCATGCTCC } \\
\text { GACCCTTTTTCCCTTCTTTGTGTTTGC } \\
\text { CGTGAATGTTCACATGTGCTTAAAGCC } \\
\text { GCCTTAATGAGATCCCTTTCCAGTATC } \\
\text { AAGTCAGCCTTGTGGGCCTCACTGTGC } \\
\text { GCCTTGTGATGACTTCACTCGGGCC }\end{array}$ & $\begin{array}{l}1 \mathrm{~A} 1 \\
1 \mathrm{~A} 2 \\
2 \mathrm{~A} \\
3 \mathrm{~A} \\
4 \mathrm{~A} \\
5 \mathrm{~A} \\
6 \mathrm{~A} \\
7 \mathrm{~A} \\
8 \mathrm{~A} \\
9 \mathrm{~A} \\
10 \mathrm{~A}\end{array}$ & $\begin{array}{l}\text { CGCTCAGGCACTGCTCCTCGTGC } \\
\text { TAGGGGCGCTCCCCGGCCTACTT } \\
\text { GGGAGAAGGACTCCACTTGGTTC } \\
\text { TCCTCCGGTCCCAAGGACCCAGACG } \\
\text { CAGGTATAAGTTACTGTGGAAAGGC } \\
\text { AGGTGCCAGTCAGCAAGGCCTACG } \\
\text { GGGCCAAAGAGTCCATCAGTAAGGAAC } \\
\text { GAAAGGAGCTCTTGAACCATGTTTGCC } \\
\text { AAGAGAATCATGAAATCAACCCTAGCC } \\
\text { CGCACTATTCCTTCTCTCAACTGAGTC } \\
\text { TGGGACACTGAACGGTCCCCGAGGG }\end{array}$ & $\begin{array}{l}286 \\
256 \\
192 \\
185 \\
202 \\
167 \\
220 \\
260 \\
217 \\
300 \\
244\end{array}$ & $\begin{array}{l}59 \\
57 \\
59 \\
62 \\
59 \\
61 \\
62 \\
58 \\
62 \\
59\end{array}$ \\
\hline
\end{tabular}

The temperatures given refer to the optimised annealing conditions used for the PCR reactions. 
samples analysed: $\mathrm{S} 12$ and $\mathrm{R} 7$ showed abnormal banding in exon 8 and CAM114 in exon 9. The true hermaphrodite patient also showed aberrant banding in exon 8 . The exon 8 results are shown in fig 1A. A group of 21 DNA samples from normal controls was also analysed for abnormal banding in exon 8 , and no variation was found. These results suggested that the variation in banding detected on SSCP gels could account for the clinical phenotype in these patients.

Evidence of polymorphism was seen in the exon 3, 7, and 10 PCR products. The variation in banding pattern was detected in normal DNA controls as well as the clinical samples, and presumably represents neutral polymorphism. An example of the exon 7 polymorphism is shown in fig 1B. Sequence analysis showed that this polymorphism changes the ninth base of exon 7 from A to $G$, and corresponds to the polymorphism reported previously at nucleotide $600 .^{5}$ The polymorphism was also recently reported in a separate SSCP study of the WT1 gene. ${ }^{31}$ The base change occurs in the third position of the codon for arginine and does not result in an amino acid change in the WT1 protein. Analysis of 44 subjects showed that the allele frequencies were $15 \%$ (G) and $85 \%$ (A) (results not shown). Further polymorphisms have been previously reported in, or close to, exons 3, 6, 7 , and $10 .^{5719}$

No other aberrant banding patterns were detected. In particular, the patients with abnormal genital phenotypes alone showed no evidence of WT1 mutation.
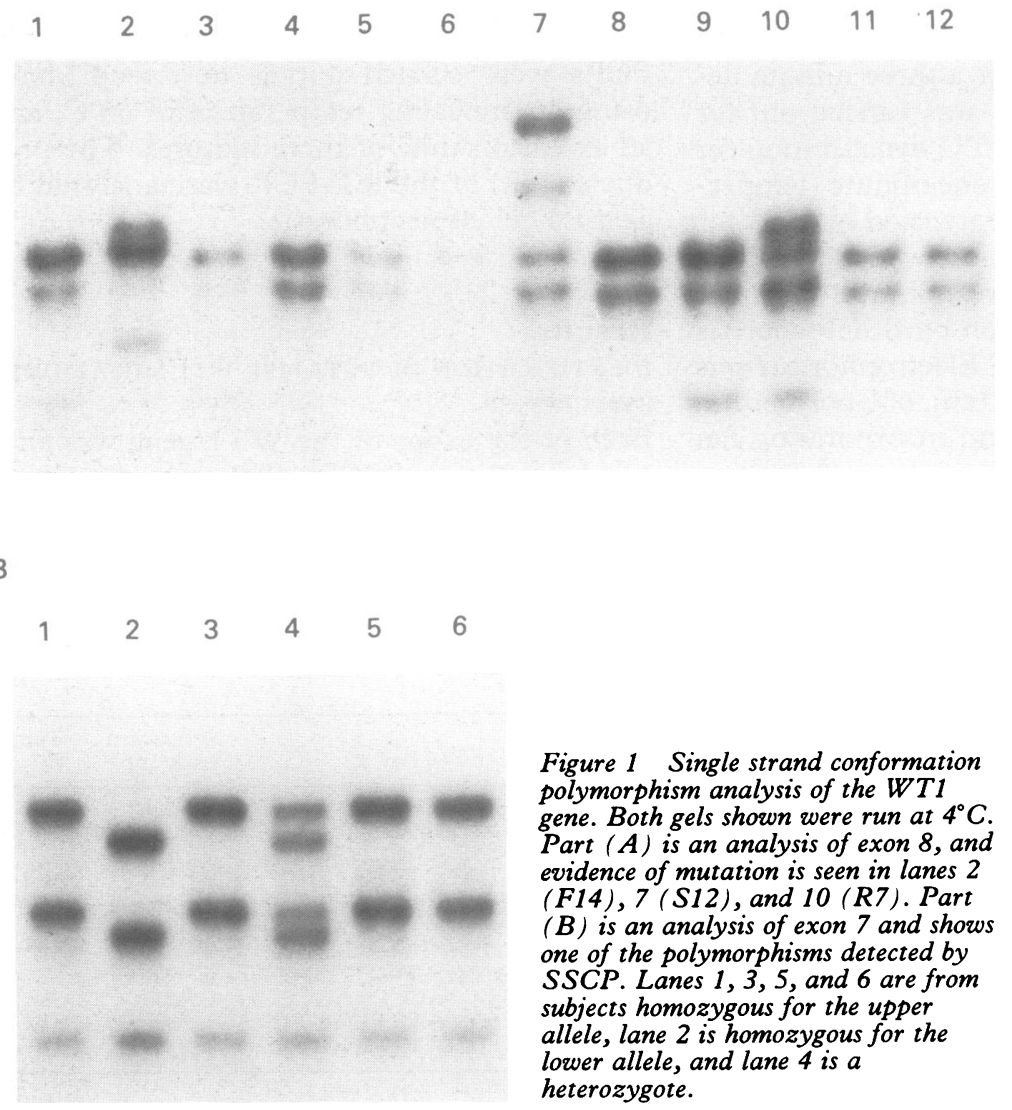

CHARACTERISATION AND ANALYSIS OF WT MUTATIONS

The PCR fragments which migrated aberrantly on SSCP gels were sequenced directly. The sequence of the PCR fragment containing exon 8 in the true hermaphrodite F14 showed a heterozygous point mutation in the flanking intron 8 DNA (results not shown). This altered the ninth nucleotide in the intron from $G$ to $A$. This position is outside the splice donor consensus sequence, ${ }^{32}$ but since an effect on splicing could not be ruled out, an RT-PCR experiment was designed to test for abnormal splicing of the WT1 transcript. A single PCR reaction on cDNA reverse transcribed from genital skin fibroblast RNA did not give a product which could be detected on agarose gels. Nested PCR was therefore carried out using sense primers from exon 7 and exon 9 antisense primers. When visualised on a $1.2 \%$ agarose gel F14 showed a single band of normal size $(225 \mathrm{bp})$, present also in an unaffected control sample. This suggests that splicing is not affected by the intron 8 mutation in F14. We conclude therefore that this mutation is unlikely to have an effect on WT1 expression and is not the cause of the clinical phenotype in this patient.

Figure 2 shows the sequencing gels which showed mutations in the DDS patients. The exon 8 WT1 mutation in S12 was heterozygous and resulted in the substitution of codon arginine 362 for a termination codon (fig 2A). This mutation was identified independently in Wilms's tumour tissue from this patient, and was found to be homozygous in the tumour. ${ }^{23}$ In patient $\mathrm{R} 7$, a heterozygous point mutation was found in exon 8 which converted codon cysteine 360 to tyrosine (fig 2B). The third DDS patient, CAM114, carried the exon 9 mutation which has been found in the majority of DDS patients and changes arginine 394 to tryptophan (fig 2C). This patient was investigated in an independent study and the mutation has been reported. ${ }^{15}$

\section{Discussion}

This study was initially prompted by the large number of patients with the clinical diagnosis of the partial androgen insensitivity syndrome, but in whom normal androgen binding activity and, by SSCP analysis, a normal androgen receptor gene were found. ${ }^{20}$ Mutations in genes other than the androgen receptor gene may therefore account for the genital phenotypes in these patients. Given the evidence of a role for WT1 in genital development, we screened WT1 for mutation in such patients. A total of $1246, \mathrm{XY}$ patients with various genital abnormalities were screened. Seven patients had a testosterone response to hCG stimulation or gonadal histology consistent with a diagnosis of PAIS or both (P4, Y7, H16, X14, G14, A15, H8). We also included three patients whose gonadal phenotype was not consistent with PAIS (C7, H6, F14). Gonadal histology or hCG stimulation data was not available for the remaining two patients (P1, F12). All patients had normal androgen bind- 
A
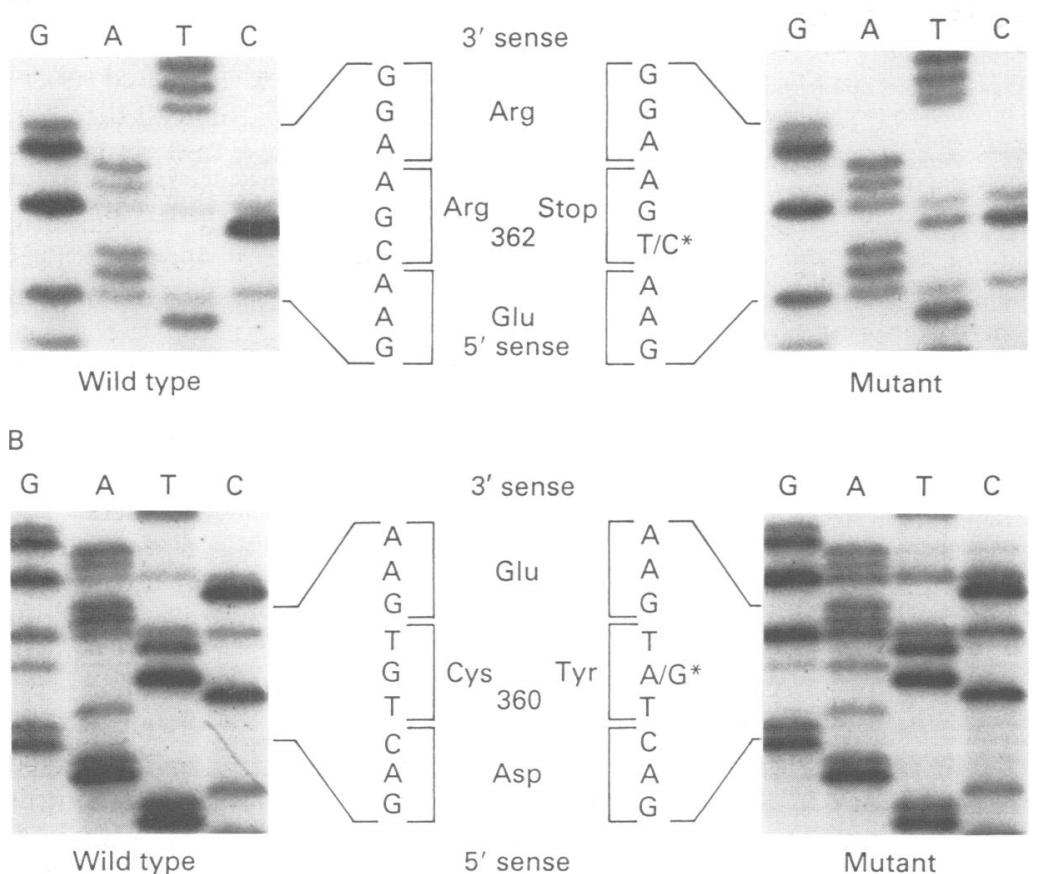

C

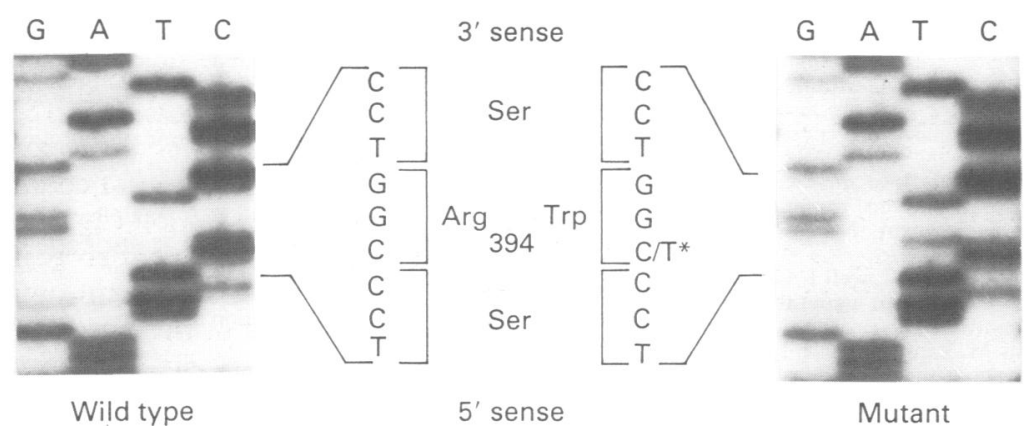

Figure 2 Sequence analysis of three of the WT1 mutations detected in DDS patients. Normal and mutant sequences are shown. The asterisks indicate the position at which a new band is seen in the mutant sample, indicating the presence of a heterozygous WTI mutation. The predicted consequences of the mutations on the coding potential of the gene are shown in the centre. Part $(A)$ shows the mutation detected in S12, part $(B)$ the mutation in $R 7$, and part $(C)$ the mutation in $C A M 114$.

ing activity. Based on SSCP analysis we have not found evidence of WT1 mutations in these subjects, with the exception of the true hermaphrodite, F14. However, for the reasons discussed above, we believe that the intronic WT1 mutation detected is a rare neutral polymorphism, unconnected with the clinical phenotype in this patient. It is possible that mutations may have been undetected by SSCP, or that mutations may be present in the $5^{\prime}$ part of exon 1 , which was not possible to analyse owing to difficulties in PCR amplification of this region. However, polymorphisms were detected and mutations were found in all three DDS patients as expected. We can conclude, therefore, that WT1 mutations may only rarely if ever give rise to genital abnormalities, when these occur in the absence of kidney dysfunction. However, it must be emphasised that the kidney abnormalities associated with DDS usually manifest at several months of age. Infants with ambiguous genitalia should therefore be considered at risk from DDS, as has been noted previously. ${ }^{33}$

The DDS patients were included in the study as positive controls since mutations were expected in the WT1 gene. SSCP band shifts were detected and subsequently point mutations were identified in each case. These mutations support the notion that DDS is caused by a dominant mutation in WT1 which disrupts DNA binding. The mutation identified in patient $\mathrm{S} 12$ is particularly informative, since the stop codon introduced at amino acid 362 in exon 8 would be expected to remove three of the four zinc fingers, thus completely abolishing DNA binding. A similar mutation which results in truncation of the WT1 protein as the result of a frameshift mutation in exon 6 was recently reported. ${ }^{15}$ The CAM 114 mutation has been detected in the majority of DDS patients and has been shown to reduce DNA binding activity of $\mathrm{WT} 1^{13}$. The $\mathrm{R} 7$ mutation has not been reported previously and substitutes a tyrosine for cysteine 360 postulated to coordinate the zinc ion in the third zinc finger. ${ }^{3}$ Such a change would be expected to have a profound effect on the structure of this zinc finger, and thus would also disrupt DNA binding.

The identification of WT1 mutations in DDS patients provides strong evidence of a role for WT1 in genital as well as kidney development. However, the variety of genital phenotypes observed, even among patients carrying the same WT1 mutation, does not provide a clear idea of the precise function of WT1 in genital development. ${ }^{13-15}$ Although the majority of DDS patients have dysgenetic gonads, it is not clear whether WT1 has a primary role in gonadal development which leads to secondary genital abnormalities. Two of the DDS patients (S12 and R7) in this study, for example, have apparently normal testes on the basis of histological and endocrinological investigations, and yet have severely undervirilised genitalia. Furthermore, these patients have no evidence of internal Müllerian structures suggesting that the testes also synthesised sufficient Müllerian inhibiting substance during development to produce a normal male internal genital phenotype. Whatever the role of WT1 in genital development, we have not found any examples of WT1 mutations which cause genital abnormalities in the absence of nephropathy. This may reflect the fact that WT1 performs a common function in kidney and genital development. In genital development, however, the effects of WT1 mutations may be mitigated by genetic background. Our results also suggest that further genes must be identified and screened for mutation to understand more completely the genetic basis of abnormal male sexual development.

We would like to thank the other members of the Department of Paediatrics and Dr Jenny Batch for helpful discussion. We are grateful to Dr Veronica van Heyningen and Professor Nick Hastie for the communiction of unpublished data and to Dr Sue Kenwrick for comments on the manuscript. We are grateful to the many clinicians who have provided samples and clinical information on the 
patients studied in this work. This research was supported by the Wellcome Trust.

1 Grumbach M, Conte F. Disorders of sexual differentiation. In: Wilson J, Foster D, eds. Williams textbook of endocrinology. 8th ed. Philadelphia: Saunders, 1992: 853-951

2 Batch J, Patterson M, Hughes I. Androgen insensitivity syndrome. Reprod Med Rev 1992;1:131-50.

3 Call $\mathrm{K}$, Glaser $\mathrm{T}$, Ito $\mathrm{C}$, et al. Isolation and characterisation of a zinc finger polypeptide gene at the human chromosome 11 Wilms tumor locus. Cell 1990;60:509-20.

4 Gessler M, Poustka A, Cavenee W, Neve R, Orkin S, Brun G. Homozygous deletion in Wilms tumor of a zinc finger gene identified by chromosome jumping. Nature 1990;343:774-8.

5 Haber D, Buckler A, Glaser T, et al. An internal deletion within an $11 \mathrm{p} 13$ zinc finger gene contributes to the within an 11pl3 zinc finger gene contributes to the
development of Wilms' tumour. Cell 1990;61:1257-69.

6 Huff V, Miwa H, Haber D, et al. Evidence for WT1 as a Wilms' tumour (WT) gene: intragenic germinal deletion in bilateral WT. Am F Hum Genet 1991;48:997-1003.

7 Little M, Prosser J, Condie A, Smith P, van Heyningen V Hastie $N$. Zinc finger point mutations within the $W T$ gene in Wilms' tumour patients. Proc Natl Acad Sci USA 1992;89:4791-5.

8 Rauscher III F, Morris J, Tournay O, Cook D, Curran T. Binding of the Wilms' tumour locus zinc finger protein to the EGR1 consensus sequence. Science 1990;250:125962.

9 Madden S, Cook D, Morris J, Gashler A, Sukhatme V, Rauscher III F. Transcriptional repression mediated by the WT1 Wilms' tumour gene product. Science 1991;253:1550-3.

10 van Heyningen $\mathrm{V}$, Hastie $\mathrm{N}$. Wilms' tumour: reconciling genetics and biology. Trends Genet 1992;8:16-21.

11 Pritchard-Jones $\mathrm{K}$, Fleming $\mathrm{S}$, Davidson $\mathrm{D}$, et al. The candidate Wilms' tumour gene is involved in genitourinary development. Nature 1990;346:194-7.

12 Pelletier J, Schalling M, Buckler A, Rogers R, Haber D, Housman D. Expression of the Wilms' tumour gene WT in the mouse urogenital system. Genes Dev 1991;5:1345 56.

13 Pelletier J, Bruening W, Kashtan C, et al. Germline mutations in the Wilms tumor suppressor gene are associated with abnormal urogenital development in Denys-Drash syndrome. Cell 1991;67:437-47.

14 Bruening W, Bardeesy N, Silverman B, et al. Germline intronic and exonic mutations in the Wilms' tumour gen (WT1) affecting urogenital development. Nature Genet 1992;1:144-8.

15 Baird P, Santos A, Groves N, Jadresic L, Cowell J. Constitutional mutations in the WT1 gene in patients with tutional mutations in the WT gene in patients with

16 Coppes M, Liefers G, Higuchi M, Zinn A, Balfe J, Williams B. Inherited WT1 mutation in Denys-Drash synliams B. Inherited WT1 mutation in

17 Jadresic L, Leake J, Gordon I, et al. Clinicopathologic review of twelve children with nephropathy, Wilms' tumour and genital abnormalities (Drash syndrome). $\mathcal{F}$ Pediatr 1990;117:717-25.

18 Eddy A, Mauer S. Pseudohermaphroditism, glomerulopathy, and Wilms' tumour (Drash syndrome): frequency in end stage renal failure. $\mathcal{Y}$ Pediatr $1985 ; 106: 584-7$.

19 Pelletier J, Bruening W, Li F, Haber D, Glaser T, Housman D. WT1 mutations contribute to abnormal genital system development and hereditary Wilms' tumour. Nature 1991;353:431-4.

20 Batch J, Williams D, Davies H, et al. Androgen receptor gene mutations identified by SSCP in fourteen subjects with androgen insensitivity syndrome. Hum Mol Genet 1992;1:497-503.

21 Turleau C, Niaudet P, Sultan C, et al. Partial androgen receptor deficiency and mixed gonadal dysgenesis in Drash syndrome. Hum Genet 1987;75:81-3.

22 Hughes I. The gonads. In: Handbook of endocrine investigations in children. London: Butterworth, 1989:111-12.

23 Little $M$, Williamson $K$, Mannens $M$, et al. Evidence that WT1 mutations in Denys-Drash syndrome patients may act in a dominant-negative fashion. Hum Mol Genet 1993;2:259-64.

24 Crawshaw P, Watson A, Rance C. Intussusception nephrosis and Drash syndrome. Eur $\mathcal{F}$ Pediatr 1991;150:813-14.

25 Evans B, Jones T, Hughes I. Studies of the androgen receptor in dispersed fibroblasts: investigation of patients with androgen insensitivity. Clin Endocrinol 1984;20:92105.

26 Chomczynski P, Sacchi N. Single-step method of RNA isolation by acid guanidinium thiocyanate-phenolchloroform extraction. Anal Biochem 1987;162:156-9.

27 Orita M, Suzuki Y, Sekiya T, Hayashi K. Rapid and sensitive detection of point mutations and DNA polymorphisms using the polymerase chain reaction. Genomics 1989;5:874-9.

28 Orita $M$, Sekiya $T$, Hayashi K DNA sequence polymorphisms in Alu repeats. Genomics 1990;8:271-8.

29 Haber D, Sohn R, Buckler A, Pelletier J, Call K, Housman $D$. Alternative splicing and genomic structure of the Wilms' tumour gene WT1. Proc Natl Acad Sci USA 1991;88:9618-22.

30 Gessler M, König A, Bruns G. The genomic organisation and expression of the WT1 gene. Genomics 1992;12:80713.

31 Groves N, Baird P, Hogg A, Cowell J. A single base pair polymorphism in the WT1 gene detected by single-strand conformation polymorphism analysis. Hum Genet 1992;90:440-2.

32 Mount S. A catalogue of splice junction sequences. Nucleic Acids Res 1982;10:459-72.

33 Hutson J, Werther G. Pseudohermaphroditism, glomerulopathy and Wilms' tumour (Drash syndrome): a case report. $\mathcal{F}$ Paediatr Child Health 1990;26:227-9. 